\title{
ANALISIS TERHADAP FAKTOR-FAKTOR DETERMINAN DALAM IMPLEMENTASI KURIKULUM MUATAN LOKAL
}

\author{
Mursid Triasmanto ${ }^{1}$ dan Laksmi Dewi ${ }^{2}$ \\ ${ }^{1}$ Kementerian Pendidikan dan Kebudayaan dan ${ }^{2}$ Universitas Pendidikan Indonesia \\ e-mail: mursid.triasmanto@kemdikbud.go.id
}

\begin{abstract}
Abstrak
Pengkajian terhadap implementasi kurikulum sangat penting termasuk pada kurikulum muatan lokal dengan karakteristik kedaerahannya. Penelitian ini bertujuan untuk menganalisis faktor-faktor determinan dalam implementasi kurikulum. Faktor-faktor determinan yang menjadi kajian utama penelitian ini adalah persepsi guru terhadap implementasi kurikulum muatan lokal, pelaksanaan pembelajaran muatan lokal yang dilakukan guru, dan dukungan terhadap guru dalam implementasi kurikulum muatan lokal. Metode penelitian yang digunakan adalah survei dengan pendekatan kuantitatif. Sampel penelitian adalah guru mata pelajaran muatan lokal, yang dipilih dengan menggunakan teknik random sampling. Sampel guru terpilih diminta menyatakan sikap dan pendapatnya terkait variabel penelitian melalui pengisian instrumen penelitian berupa kuesioner tertutup, dengan skala Likert. Teknik uji instrumen yang digunakan adalah uji keterpahaman, validitas, dan reliabilitas. Data yang berhasil dihimpun kemudian dianalisis menggunakan analisis persentase dan uji t. Hasil penelitian mendeskripsikan bahwa tidak ada perbedaan persepsi guru terhadap implementasi kurikulum muatan lokal $\left(\mathrm{X}_{1}\right)$, pelaksanaan pembelajaran yang dilakukan oleh guru $\left(\mathrm{X}_{2}\right)$, dan dukungan guru dalam implementasi kurikulum muatan lokal $\left(\mathrm{X}_{3}\right)$ antara guru yang mengajar di satuan pendidikan berstatus negeri dan juga swasta. Simpulan yang diperoleh, persepsi guru terhadap pembelajaran sebaiknya ditingkatkan, terutama keyakinan dalam diri guru untuk melandasi pelaksanaan pembelajaran yang terstruktur agar berdampak positif bagi siswa. Dukungan stakeholder pun berimplikasi signifikan terhadap pelaksanaan pembelajaran muatan lokal sehingga perlu dijamin keberadaannya.
\end{abstract}

Kata Kunci: faktor-faktor determinan, implementasi kurikulum, persepsi guru, pelaksanaan pembelajaran, dukungan

\section{ANALYSIS OF DETERMINANT FACTORS IN THE IMPLEMENTATION OF LOCAL CONTENT CURRICULUM}

\begin{abstract}
Research on local content curriculum is very important with its regional characteristics. This study aims to analyze the determinant factors in curriculum implementation. Determinant factors that became the main study of this research were teachers' perceptions of local content curriculum implementation, the local content learning conducted by teachers, and support to teachers in the implementation of local content curriculum. This research uses survey method with quantitative approach. The research sample was the local subject matter teachers, selected using random sampling technique. Selected teacher samples are asked to state their tendencies and opinions related to research variables by filling the research instrument in the form of a closed questionnaire, with a Likert scale. The instrument testing technique used is comprehension, validity, and reliability test. Data collected is then analyzed using percentage analysis and independentsamples t test. The results of the study describe the fact that there is no difference in teacher perceptions of the implementation of the local content curriculum (X1), implementation of learning carried out by teachers (X2), and teacher support in the implementation of local
\end{abstract}


transport curriculum (X3) between teachers teaching in state status education and also private. The conclusion are teachers' perceptions of learning should be improved, especially teachers beliefs to underpin the implementation of structured learning in order to positively impact students. Stakeholder support also has significant implications for the learning implementation so it needs to be guaranteed.

Keywords: determinant factors, curriculum implementation, teachers' perceptions, local content learning, support

\section{PENDAHULUAN}

Kualitas sumber daya manusia dapat ditingkatkan secara efektif melalui pendidikan formal. Jumlah penduduk yang besar dan keberagaman wilayah di Indonesia menjadi pekerjaan besar bagi pemerintah dalam merencanakan pendidikan bagi warganya. Kurikulum pendidikan Indonesia selain bertujuan meningkatkan mutu manusia Indonesia, diharapkan pula mampu mengembangkan potensi bangsa termasuk pemertahanan kekayaan dan budaya-budaya daerah sebagai identitas bangsa.

Budaya lokal yang beraneka warna mencerminkan keadaan sosial masingmasing wilayah, termasuk adat istiadat, cerita rakyat, ritual kedaerahan, hingga lagu-lagu daerah (Muhyidin, 2009), sehingga lebih tepat jika difasilitasi oleh kurikulum yang bersifat kedaerahan. Hal tersebut menjadi tantangan bagi para pengembang kurikulum di daerah dalam mengkaji nilai budaya daerah dan potensipotensi lokal. Prioritas kebutuhan setiap daerah khususnya dalam ranah pendidikan perlu dikenali dengan seksama oleh para pengembang kurikulum di daerah dan perlu dijadikan sebagai aspek yang terus ditinjau secara rutin agar senantiasa relevan dengan perkembangan yang ada (Ririmasse, 2014).

Dewasa ini, aspek sikap dan mental bangsa memerlukan perhatian dari pendidikan. Globalisasi selain menawarkan keterbukaan informasi dan kesempatan untuk mengembangkan potensi diri, juga melahirkan kekhawatiran tersendiri. Gesekan budaya yang lazim terjadi, menuntut pendidikan mampu membangun pagar untuk menjaga khasanah budaya timur bangsa dari pengaruh budaya asing yang bertendensi negatif. Suyatno (2011) dalam kajiannya mencermati bahwa kekayaan budaya bangsa seperti nilai, akar tradisi, dan kearifan lokal mulai terkikis dan tergerus perlahan.

Pemerintah Daerah Provinsi Jawa Barat menyadari kebutuhan akan upaya pemertahanan kebudayaan daerah dengan menetapkan Peraturan Gubernur Jawa Barat No. 69 Tahun 2013 tentang Pembelajaran Muatan Lokal Bahasa dan Sastra Daerah pada Jenjang Pendidikan Dasar dan Menengah. Arifin (2014) menyatakan bahwa muatan lokal berisi materi atau bahan pelajaran yang bersifat lokal. Pengajaran bahasa daerah di sekolah merupakan suatu upaya strategis yang ditempuh oleh pemerintah daerah dalam melakukan pembinaan penggunaan bahasa daerah di masyarakat (Suyanto, 2015). Melalui penetapan kebijakan tersebut, sekolah mendorong apresiasi siswa untuk berbahasa daerah, meng-angkat kembali nilai-nilai luhur bangsa dan kebanggaan terhadap kebudayaan daerahnya. Upaya Pemerintah Daerah Provinsi Jawa Barat ini juga selaras dengan Peraturan Menteri Pendidikan dan Kebudayaan No. 79 Tahun 2014 tentang Muatan Lokal Kurikulum 2013.

Kebudayaan Sunda pada dasarnya merupakan sistem nilai masyarakat yang berbahasa Sunda, karena itu sistem nilai dirumuskan melalui bahasanya (Sumardjo, 2011). Upaya revitalisasi ba-hasa daerah melalui penetapan kebijakan dan juga pembelajaran sudah dilakukan, namun fenomena di lapangan belum menunjukkan hasil yang diinginkan. Sikap negatif penutur bahasa daerah masih terlihat. Pendapat bahwa berbahasa daerah terlalu rumit dan ragam bahasa yang tidak praktis 
dengan adanya undak unduk basa menjadi alasan generasi muda kurang antusias berbahasa Sunda. Lingkungan sosial siswa seperti keluarga, lingkungan pendidikan, dan media komunikasi pun menjadi faktor yang turut mempengaruhi sikap penutur bahasa Sunda (LIPI, 2015).

Media Pikiran Rakyat pada tahun 2010 pernah menyatakan bahwa dari satu generasi ke generasi berikutnya jumlah penutur yang menguasai bahasa Sunda di Jawa Barat turun dua puluh persen. Pernyataan tersebut merujuk pada hasil penelitian Balai Bahasa Bandung yang mendapati bahwa dari 850 responden pasangan suami istri di Jawa Barat, terdapat 754 pasangan suami istri yang dapat berbahasa Sunda. Dari jumlah pasangan yang bisa berbahasa Sunda tersebut lahir 565 anak yang mampu berbahasa Sunda. Mirip dengan hasil penelitian Balai Bahasa Bandung, Kepala Balai Pengelolaan Taman Budaya Jawa Barat (Heriyanto, 2017) juga menambahkan bahwa secara perlahan ragam bahasa Sunda mulai hilang, banyak lagam atau logat masyarakat pesisir selatan, utara, dan pegunungan yang mulai kehilangan penutur. Bukan hanya di perkotaan, di daerah pedesaan pun lambat laun jumlah penutur bahasa daerah semakin turun.

Penutur Bahasa Sunda berjumlah sekitar 32 juta orang $(15,14 \%)$ dan merupakan bahasa dengan jumlah penutur terbanyak ketiga setelah penutur Bahasa Jawa dan Bahasa Indonesia (Pusat Data dan Statistik Pendidikan dan Kebudayaan, 2016). Meski jumlah penutur besar, kekhawatiran akan kelestarian bahasa daerah masih dirasakan oleh Gubernur Jawa Barat terkait dengan tren jumlah penutur bahasa daerah yang kian turun. Sebagian besar masyarakat Sunda menghindari menggunakan bahasa ibu karena khawatir penggunaan bahasa ibu akan menghambat komunikasi, dan menganggap bahwa penggunaan bahasa daerah sudah tidak lagi tepat di era globalisasi ini (Rep-Humas Setda Jabar, 2016). Lewis, dkk., (Budiwiyanto, 2016) memberikan ciri terancam punahnya suatu bahasa, yaitu jika dari sisi jumlah penutur semakin berkurang dan ketika semakin sedikit penggunaannya di kegiatan sehari-hari. Kekhawatiran punahnya bahasa daerah cukup berdasar, karena dengan hilangnya suatu bahasa maka hilang pula aspek kebahasaan didalamnya dan juga kebudayaan masyarakat penutur yang melekat pada bahasa tersebut (Tondo, 2009).

Pada dasarnya penutur merupakan penentu keberadaan bahasanya sendiri (Natadipura, 2015). Lembaga-lembaga internasional sudah berupaya mengangkat kembali bahasa daerah melalui himbauan dan penetapan hari khusus untuk bahasa ibu, pemerintah telah bertindak dengan menetapkan undang-undang perlindungan bahasa daerah, namun jika penuturnya sendiri bersikap negatif pada bahasanya maka langkah-langkah revitalisasi bahasa daerah tidak akan berdampak signifikan. Bila sekarang ini bahasa daerah kurang disukai penuturnya sendiri, muncul asumsi bahwa ada kekeliruan pada strategi pemertahanan kebudayaan dan bahasa daerah, dan juga memperlihatkan rendahnya kesetiaan penutur terhadap bahasa daerahnya (Badan Pengembangan dan Pembinaan Bahasa, 2017).

Permasalahan lain yang terkait dengan eksistensi bahasa daerah di Indonesia adalah persaingan dengan bahasa lain. Penggunaan bahasa Indonesia contohnya, saat ini penggunaannya tidak sebatas di ranah tinggi kenegaraan, administrasi publik, pengantar pendidikan dan lainnya, namun sudah masuk ke ranah rendah seperti keluarga dan kekariban. Pada ranah keluarga, loyalitas penutur terhadap bahasa daerah justru mengalami penurunan (Yati, 2015). Padahal ranah alami bahasa ibu adalah di keluarga. Antusiasme penutur berbahasa daerah menjadi bukti telah tergusurnya bahasa ibu di ranahnya. Bahasa asing juga turut menekan keberadaan bahasa ibu. Ranah Pendidikan sebagai media strategis untuk menjaga bahasa dan budaya daerah seakan tidak menyadari permasalahan yang kian 
meresahkan ini. Pendidikan seharusnya mampu menyelesaikan persaingan bahasa melalui penempatan bahasa-bahasa yang ada sesuai kedudukan dan ranahnya masing-masing (Sobarna, 2007).

Implementasi kurikulum muatan lokal Bahasa dan Sastra Sunda di Jawa Barat sebagai salah satu upaya dalam melestarikan bahasa dan budaya daerah perlu dikaji relevansinya. Sasaran pokok muatan lokal adalah mengakrabkan siswa dengan nilai sosial budaya masyarakat dan meningkatkan kepedulian siswa pada lingkungannya (Suyitno, 1999). Pembelajaran muatan lokal secara konseptual mengacu pada pendekatan place-based education, siswa ditekankan agar kreatif menanggapi fenomena dan isu-isu lingkungan sehingga mereka mampu memposisikan diri di dalam masyarakatnya, tidak pasif hanya sebatas menjadi pengamat (Sobel, 2004). Pendekatan ini memberi siswa kesempatan untuk belajar dengan cara yang otentik, menghubungkan pembelajaran baru dengan pengalaman hidup sebelumnya, dan aktif melibatkan siswa dalam memahami apa yang mereka pelajari (Howley, A., dkk., 2011). Pembelajaran bahasa daerah di sekolah merupakan langkah strategis pemerintah daerah dalam meningkatkan penggunaan bahasa daerah di masyarakat (Suyanto, 2015).

Salah satu indikator keberhasilan pelaksanaan kurikulum muatan lokal di sekolah adalah adanya pengelolaan yang baik, mulai dari perencanaan, pelaksanaan, dan evaluasi muatan lokal yang bersangkutan (Lestari, 2012; Wahyudin, 2014). Implementasi kurikulum merupakan aktualisasi dokumen ke dalam wujud pembelajaran, sejalan dengan pendapat Miller \& Seller (1985) yang mengungkapkan bahwa "in some case, implementation has been identified with instruction". Kurikulum aktual mengatur interaksi guru, siswa, dan lingkungan pembelajaran (Mulyasa, 2010). Hasil dari implementasi kurikulum muatan lokal telah tertera jelas dalam Permendikbud No. 79 Tahun 2014 dan Peraturan Gubernur Jawa Barat No. 69 Tahun 2013, namun implementasi kuriku- lum merupakan kegiatan yang kompleks mengingat beragamnya pengguna dan sumber daya yang ada. Implementasi kurikulum memerlukan kesiapan yang menyeluruh, mulai dari guru, anggaran, sarana dan prasarana, siswa, bahan (material), manajemen di sekolah dan kesiapan dari administrator terkait (Sukmadinata, 2016). Kerumitan transfer informasi dari pengembang ke pengguna perlu dipertimbangkan, mulai dari karakteristik kurikulum, strategi sosialisasi, dan karakteristik pengguna (Hamalik, 2009). Setiap kurikulum memi-liki kekhasan tersendiri terkait tujuan, ruang lingkup, bahan ajar, metode dan pendekatan, serta evaluasinya. Informasiinformasi tersebut perlu dipahami oleh guru sebagai pengggunanya.

Kesenjangan berupa sikap negatif penutur dan persaingan dengan bahasa lain pada akhirnya merujuk pada pertanyaan: mengapa implementasi kurikulum muatan lokal belum mampu mendukung upaya revitalisasi bahasa daerah? Pertanyaan tersebut akan dijawab dengan mengungkap faktor-faktor determinan yang mempengaruhi implementasi kurikulum. Guru dan tanggung jawabnya menjadi aspek sentral dalam penelitian ini, karena pada dasarnya implementasi kurikulum memiliki implikasi langsung bagi pendidikan guru dan staf yang bekerja di sektor pendidikan (Barton, Garvis \& Ryan, 2014; Mansur, 2012). Faktor-faktor determinan dalam penelitian ini dianggap sebagai indikator keber-hasilan implementasi kurikulum. Persepsi guru terhadap implementasi kurikulum, proses pelaksanaan pembelajaran yang dilakukan, dan dukungan untuk guru dalam implementasi kurikulum merupa-kan faktor-faktor determinan yang akan dikaji untuk mengungkap kesenjangan yang terjadi dalam implementasi kuriku-lum.

Faktor yang pertama adalah persepsi guru. Persepsi guru yang tepat akan mendukung keberhasilan implementasi kurikulum, guru harus yakin bahwa perubahan yang diusung oleh kurikulum akan berdampak positif bagi siswa 
(Ornstein \& Hunkins, 2017). Persepsi juga berupa keterbukaan dan kesediaan guru untuk mengubah pola pikir sesuai paradigma kurikulum (Mulyasa, 2016), sikap positif, optimis, keinginan kuat untuk menerapkan kurikulum, dan upaya guru untuk memahami rasionalisasi kurikulum, landasan filosofis, elemenelemen utama, dan strategi implementasi kurikulum yang dibutuhkan (Komunitas Sekolah Riset Small Intense Class, 2014). Tanpa persepsi yang tepat, tujuan kurikulum akan lebih sulit tercapai.

Faktor yang kedua, pelaksanaan pembelajaran yang dipandu oleh guru. Faktor ini terkait dengan kegiatan-kegiatan yang dilakukan guru dalam merancang, melaksanakan dan mengevaluasi pembelajaran di kelas. Indikator pelaksanaan pembelajaran ini mengacu pada Peraturan Menteri Pendidikan dan Kebudayaan (Permendikbud) No. 16 Tahun 2007 tentang Standar Kualifikasi Akademik dan Kompetensi Guru. Penyelenggaraan pembelajaran, penguasaan kompetensi, pengembangan materi ajar, pemanfaatan teknologi informasi dan komunikasi, pemahaman karakteristik siswa, pengembangan kurikulum, fasilitasi potensi siswa, komunikasi yang dibangun, dan penyelenggaraan evaluasi dan peman-faatannya. Kurikulum sebaik apapun akan sulit mencapai tujuan tanpa proses pembelajaran yang terencana dan terarah. Pembelajaran yang sistematis memudahkan proses identifikasi terhadap hasil yang akan didapat.

Faktor ketiga adalah dukungan terhadap guru dalam implementasi kurikulum. Implementasi kurikulum mengaitkan interaksi pihak-pihak terkait dan merancangnya sedemikian rupa agar pembelajaran berlangsung dengan baik. Ada enam dimensi yang dukungan yang menjadi fokus penelitian yaitu dukungan berupa pelatihan/sosialisasi/workshop tentang kurikulum muatan lokal, penciptaan budaya/iklim sekolah yang kondusif bagi pembelajaran, dukungan kepala sekolah, dukungan rekan sejawat, dukungan masyarakat sekitar sekolah, dan dukungan orang tua. Berbagai dukungan diperlukan oleh guru agar kurikulum dapat diterapkan dengan baik, mulai dari dukungan internal guru sendiri, dukungan pemerintah daerah, pengembang kurikulum, kepala sekolah dan juga rekan sejawat. Bentuknya dapat berupa pening-katan finansial, dan juga dukungan moril (Musfah, 2015). Hussain, Adeeb, \& Aslam (2011) dalam kajiannya juga me-nyatakan bahwa implementasi kurikulum perlu mempertimbangkan pelatihan in-service untuk guru. Penciptaan kondisi belajar yang kondusif juga dapat menjadi dukungan bagi guru untuk melaksanakan pembelajaran (Rusman, 2012).

Berdasarkan pemikiran yang telah disampaikan, penulis bermaksud meneliti faktor-faktor determinan yang dapat mempengaruhi implementasi kurikulum muatan lokal sehubungan dengan upaya pendidikan dalam melestarikan bahasa daerah. Secara lebih spesifik penelitian ini bertujuan untuk mengetahui persepsi guru tentang implementasi kurikulum muatan lokal, mengetahui pelaksanaan pembelajaran muatan lokal yang dilakukan guru, dan untuk mengetahui dukungan terhadap guru dalam mengimplementasikan kurikulum muatan lokal.

\section{METODE}

Penelitian ini dilakukan sebagai upaya memperoleh informasi tentang faktorfaktor determinan yang mempe-ngaruhi implementasi kurikulum muatan lokal di satuan pendidikan. Metode survei dengan pendekatan kuantitatif dipilih untuk meneliti sikap, perilaku, dan pendapat guruguru terkait dengan indikator penelitian.

Metode survei digunakan untuk mengumpulkan informasi tentang keberadaan faktor-faktor determinan yang yang menjadi fokus penelitian di lapangan. Pendekatan kuantitatif digunakan untuk memudahkan proses pengolahan dan analisis data survei yang jumlahnya cenderung besar. Interpretasi data secara kuantitatif diharapkan dapat meningkatkan objektivitas terhadap proses analisis data 
penelitian melalui penggunaan metodemetode statistika.

Populasi penelitian adalah guru mata pelajaran muatan lokal yang dipilih dengan teknik random sampling. Sebagai studi pendahuluan, penulis memilih 30 sampel guru muatan lokal yang mengajar di sekolah negeri dan swasta untuk kemudian diminta menyatakan sikap dan pendapatnya melalui pengisian instrumen penelitian berupa kuesioner tertutup, dengan skala Likert.

Instrumen penelitian terdiri dari 128 (seratus dua puluh delapan) butir pernyataan dengan 5 (lima) opsi jawaban menggunakan skala Likert. Bobot nilai mulai dari sangat positif (5) hingga sangat negatif (1). Instrumen dibedakan menjadi 2 bagian berdasarkan opsi jawaban yang disediakan. Instrumen bagian pertama memiliki opsi jawaban: Selalu, Sering, Kadang-Kadang, Pernah, dan Tidak Pernah. Instrumen bagian kedua memiliki opsi jawaban: Sangat Setuju, Setuju, RaguRagu, Kurang Setuju, dan Tidak Setuju.

Teknik uji instrumen yang digunakan adalah uji keterpahaman butir soal, uji validitas, dan uji reliabilitas. Uji keterpahaman dilakukan untuk mendapatkan masukan terkait kesesuaian pernyataan yang digunakan dalam instrumen.

Uji validitas dilakukan dengan menghitung korelasi antara skor setiap butir pertanyaan ( $\mathrm{x}$ ) dengan skor total yang didapat dari setiap responden (y). Formula korelasi yang digunakan adalah rumus korelasi product moment $\left(\mathrm{r}_{\mathrm{xy}}\right)$. Besarnya indeks korelasi hitung menunjukkan derajat validitas setiap butir pertanyaan, maka butir pernyataan dengan indeks korelasi rendah $\left(\mathrm{r}_{\mathrm{xy}}<0,40\right)$ diganti/diper-baiki (Ali, 2014).

Uji reliabilitas instrumen dilakukan dengan menggunakan Formula Cronbach Alpha $(\alpha)$. Tingkat reliabilitas diukur untuk mengetahui derajat konsistensi instrumen penelitian saat digunakan berulang (Ali, 2014; Arikunto, 2006). Hasil olah data menggunakan SPSS Statistics Version 20 menunjukkan bahwa instrumen yang digunakan reliabel, hal ini ditunjukkan oleh nilai $r$ hitung lebih besar dari $r$ tabel $(0,06)$.
Dengan demikian, instrumen penelitian tersebut layak untuk digunakan dalam pengambilan data.

Sebelum data hasil penelitian diolah ke dalam persentase dan uji-t. Penulis melakukan uji normalitas dengan formula Kolmogorov-Smirnov. Hasil perhitungan menunjukkan bahwa nilai probabilitas sub variabel persepsi guru terhadap implementasi kurikulum muatan lokal, pelaksanaan pembelajaran muatan lokal yang dilakukan guru, dan dukungan terhadap guru dalam implementasi kurikulum muatan lokal berada di atas signifikansi 0,05. Dapat disimpulkan bahwa data penelitian berdistribusi normal.

Selanjutnya, pengolahan data dilakukan dengan menghitung persentase skor hasil penelitian untuk menghitung besarnya indikator-indikator penelitian. Hipotesis penelitian dibuktikan dengan cara menghitung nilai probabilitas dengan formula Independent-Samples $T$ Test menggunakan SPSS Statistics Version 20.

Adapun tahapan penelitian yang dilakukan penulis dapat disederhanakan ke dalam 3 langkah penelitian, dimulai dengan tahap persiapan penelitian, tahap pelaksanaan dan tahap akhir. Pada tahap persiapan, penulis merumuskan rasional permasalahan, menyusun kajian pustaka, menentukan metode penelitian, menyusun instrumen, dan menentukan teknik analisis data yang akan digunakan. Perencanaan dan persiapan perizinan penelitian ke lapangan juga dilakukan pada tahap ini untuk menghindari kendala dalam mengakses data. Pada tahap pelaksanaan penelitian, penulis melakukan koordinasi ke pihak terkait dan menyebarkan kuesioner. Pada tahap akhir penelitian, penulis mengolah data hasil penyebaran kuesioner menggunakan aplikasi pengolah-an data SPSS Statistics Version 20, kemudian melakukan analisis dan pembahasan terhadap hasil penelitian.

\section{HASIL DAN PEMBAHASAN \\ Hasil}

Variabel yang diteliti dalam penelitian ini adalah faktor-faktor determinan yang 
mempengaruhi imple-mentasi kurikulum muatan lokal, yang terbagi menjadi 3 sub variabel penelitian sebagaimana ditampilkan pada tabel 1 berikut.

Tabel 1. Variabel Penelitian

\begin{tabular}{ll}
\hline Variabel & Sub Variabel \\
\hline \hline Faktor-faktor & Persepsi guru terhadap \\
determinan yang & implementasi kurikulum \\
mempengaruhi & muatan lokal $\left(\mathrm{X}_{1}\right)$. \\
\cline { 2 - 2 } implementasi & Pelaksanaan \\
kurikulum & pembelajaran muatan \\
muatan lokal. & lokal yang dilakukan \\
& guru $\left(\mathrm{X}_{2}\right)$. \\
\cline { 2 - 2 } & Dukungan terhadap guru \\
& dalam implementasi \\
& kurikulum muatan lokal \\
& $\left(\mathrm{X}_{3}\right)$. \\
\hline
\end{tabular}

Berikut disajikan data deskriptif masing-masing sub variabel.

\section{Persepsi Guru terhadap Implementasi Kurikulum Muatan Lokal ( $\left.\mathbf{X}_{1}\right)$}

Rentang skor teoritik sub variabel persepsi guru terhadap implementasi kurikulum muatan lokal $\left(\mathrm{X}_{1}\right)$ terendah adalah 12 dan tertinggi adalah 60 . Berdasarkan data hasil penelitian, statistik deskriptif menunjukkan bahwa skor terendah 39 dan skor tertinggi 59. Berdasarkan hasil perhitungan, skor ratarata dari sub variabel persepsi guru terhadap implementasi kurikulum muatan lokal $\left(\mathrm{X}_{1}\right)$ adalah 49. Median terlihat pada skor 49,50, modus terlihat pada skor 47, dengan standar deviasi sebesar 4,283. Untuk lebih jelas dapat dilihat dari Tabel 2 berikut ini.

Tabel 2. Data Deskriptif Penelitian

\begin{tabular}{lrrr}
\hline Deskripsi & \multicolumn{1}{c}{$X_{1}$} & \multicolumn{1}{c}{$X_{2}$} & \multicolumn{1}{c}{$X_{3}$} \\
\hline \hline $\mathrm{N}$ & 30 & 30 & 30 \\
Rata-Rata & 49,00 & 248,67 & 215,23 \\
Median & 49,50 & 247,50 & 217,00 \\
Modus & 47 & 247 & 183 \\
Std. Deviasi & 4,283 & 18,766 & 19,222 \\
Minimum & 39 & 214 & 183 \\
Maximum & 59 & 291 & 265 \\
\hline
\end{tabular}

Distribusi frekuensi data sub variabel persepsi guru terhadap implementasi kurikulum muatan lokal $\left(\mathrm{X}_{1}\right)$ disajikan dalam Tabel 3 berikut.

Tabel 3. Distribusi Frekuensi Data Sub

Variabel Persepsi Guru terhadap

Implementasi Kurikulum Muatan Lokal

\begin{tabular}{cccc}
\hline No. & $\begin{array}{c}\text { Kelas } \\
\text { Interval }\end{array}$ & $\begin{array}{c}\text { Frekuensi } \\
\text { (f) }\end{array}$ & $\begin{array}{c}\text { Persentase } \\
(\%)\end{array}$ \\
\hline \hline 1. & $39-42$ & 3 & 10,0 \\
2. & $43-46$ & 2 & 6,7 \\
3. & $47-50$ & 15 & 50,0 \\
4. & $51-54$ & 8 & 26,7 \\
5. & $55-58$ & 1 & 3,3 \\
6. & $59-62$ & 1 & 3,3 \\
& Total & 30 & 100,0 \\
\hline
\end{tabular}

Berdasarkan data penelitian, terdapat 2 responden $(6,7 \%)$ yang memiliki skor sama dengan rata-rata (49). Terdapat 43,3\% responden memiliki nilai di bawah nilai rata-rata dan sisanya $50 \%$ responden memiliki skor di atas rata-rata. Data menunjukkan $56,7 \%$ responden memiliki skor di atas skor rata-rata sampel. Dengan demikian, Tabel 3 memperlihatkan data yang mendekati kurva normal dimana ratarata hampir berada ditengah kurva. Kecenderungan data sub variabel persepsi guru terhadap implementasi kurikulum muatan lokal $\left(\mathrm{X}_{1}\right)$ dapat dilihat pada histogram berikut.

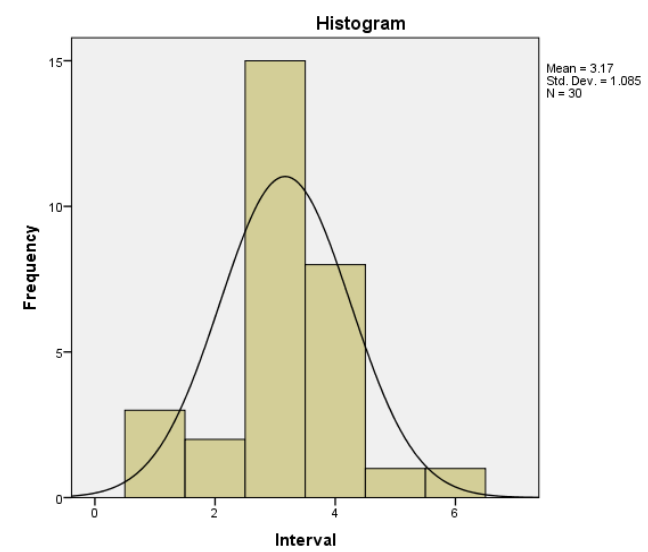

Gambar 1. Histogram Data Sub

Variabel Persepsi Guru Terhadap Implementasi Kurikulum Muatan Lokal

Pelaksanaan Pembelajaran Muatan Lokal yang Dilakukan oleh Guru ( $\left.\mathrm{X}_{2}\right)$

Rentang skor teoritik sub variabel pelaksanaan pembelajaran muatan lokal 
yang dilakukan oleh guru $\left(\mathrm{X}_{2}\right)$ terendah adalah 62 dan tertinggi adalah 310 . Berdasarkan data hasil penelitian, statistik deskriptif menunjukkan bahwa skor terendah 214 dan skor tertinggi 291. Berdasarkan hasil perhitungan, skor ratarata dari sub variabel pelaksanaan pembelajaran yang dilakukan oleh guru $\left(\mathrm{X}_{2}\right)$ adalah 248,67. Median terlihat pada skor 247,50, modus terlihat pada skor 247, dengan standar deviasi sebesar 18,766.

Distribusi frekuensi data sub variabel pelaksanaan pembelajaran yang dilakukan oleh guru $\left(\mathrm{X}_{2}\right)$ disajikan dalam Tabel 4 berikut.

Tabel 4. Distribusi Frekuensi Data Sub Variabel Pelaksanaan Pembelajaran yang Dilakukan oleh Guru

\begin{tabular}{cccc}
\hline No. & $\begin{array}{c}\text { Kelas } \\
\text { Interval }\end{array}$ & $\begin{array}{c}\text { Frekuensi } \\
\text { (f) }\end{array}$ & $\begin{array}{c}\text { Persentase } \\
(\%)\end{array}$ \\
\hline \hline 1. & $214-226$ & 3 & 10.0 \\
2. & $227-239$ & 5 & 16.7 \\
3. & $240-252$ & 10 & 33.3 \\
4. & $253-265$ & 7 & 23.3 \\
5. & $266-278$ & 3 & 10.0 \\
6. & $279-291$ & 2 & 6.7 \\
& Total & 30 & 100,0 \\
\hline
\end{tabular}

Berdasarkan data penelitian, terdapat 1 responden $(3,3 \%)$ yang memiliki skor sama dengan rata-rata $(248,67)$. Terdapat $50 \%$ responden memiliki nilai di bawah nilai rata-rata dan sisanya $46,7 \%$ responden memiliki skor di atas rata-rata. Data menunjukkan 50\% responden memiliki skor di atas skor rata-rata sampel. Dengan demikian, Tabel 4 memperlihatkan data yang mendekati kurva normal di mana skor responden hampir separuh berada di sebelah kanan dan kiri skor rata-rata. Kecenderungan data sub variabel pelaksanaan pembelajaran yang dilakukan oleh guru $\left(\mathrm{X}_{2}\right)$ dapat dilihat pada histogram berikut.

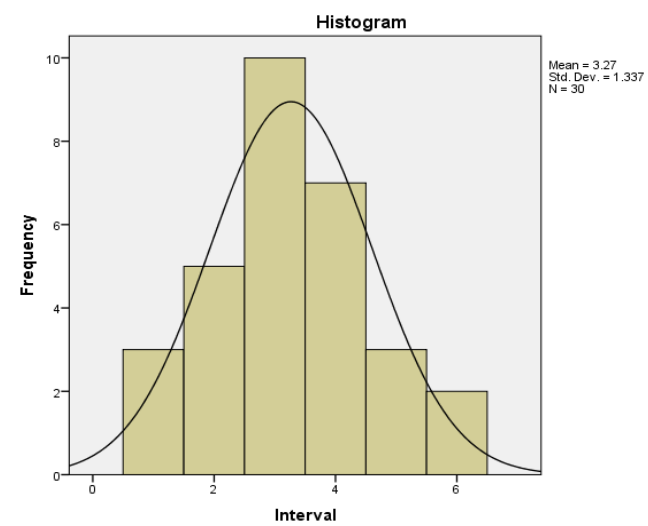

Gambar 2. Histogram Data Sub

Variabel Pelaksanaan Pembelajaran yang Dilakukan oleh Guru

\section{Dukungan Terhadap Guru dalam Implementasi Kurikulum Muatan Lokal (X)}

Rentang skor teoritik sub variabel dukungan terhadap guru dalam implementasi kurikulum muatan lokal $\left(\mathrm{X}_{3}\right)$ terendah adalah 54 dan tertinggi adalah 270. Berdasarkan data hasil penelitian, statistik deskriptif menunjukkan bahwa skor terendah 183 dan skor tertinggi 265. Berdasarkan hasil perhitungan, skor ratarata dari sub variabel dukungan terhadap guru dalam implementasi kurikulum muatan lokal $\left(X_{3}\right)$ adalah 215,23. Median terlihat pada skor 217, modus terlihat pada skor 183, dengan standar deviasi sebesar 19,222.

Distribusi frekuensi data sub variabel dukungan terhadap guru dalam implementasi kurikulum muatan lokal $\left(\mathrm{X}_{3}\right)$ disajikan dalam Tabel 5 berikut.

Tabel 5. Distribusi Frekuensi Data Sub Variabel Dukungan Terhadap Guru dalam Implementasi Kurikulum Muatan Lokal

\begin{tabular}{cccc}
\hline No. & $\begin{array}{c}\text { Kelas } \\
\text { Interval }\end{array}$ & $\begin{array}{c}\text { Frekuensi } \\
(\mathrm{f})\end{array}$ & $\begin{array}{c}\text { Persentase } \\
(\%)\end{array}$ \\
\hline \hline 1. & $183-196$ & 4 & 13.3 \\
2. & $197-210$ & 7 & 23.3 \\
3. & $211-224$ & 12 & 40.0 \\
4. & $225-238$ & 4 & 13.3 \\
5. & $239-252$ & 1 & 3.3 \\
6. & $253-266$ & 2 & 6.7 \\
& Total & 30 & 100,0 \\
\hline
\end{tabular}


Berdasarkan data penelitian, tidak ada responden $(0 \%)$ yang memiliki skor sama dengan rata-rata $(215,23)$. Terdapat $36,7 \%$ responden memiliki nilai di bawah nilai rata-rata dan sisanya $63,3 \%$ responden memiliki skor di atas rata-rata. Data menunjukkan $63,3 \%$ responden memiliki skor di atas skor rata-rata sampel. Dengan demikian, Tabel 5 memperlihatkan data yang mendekati kurva normal di mana ratarata hampir berada di tengah kurva. Kecenderungan data sub variabel dukungan terhadap guru dalam implementasi kurikulum muatan lokal $\left(\mathrm{X}_{3}\right)$ dapat dilihat pada histogram berikut.

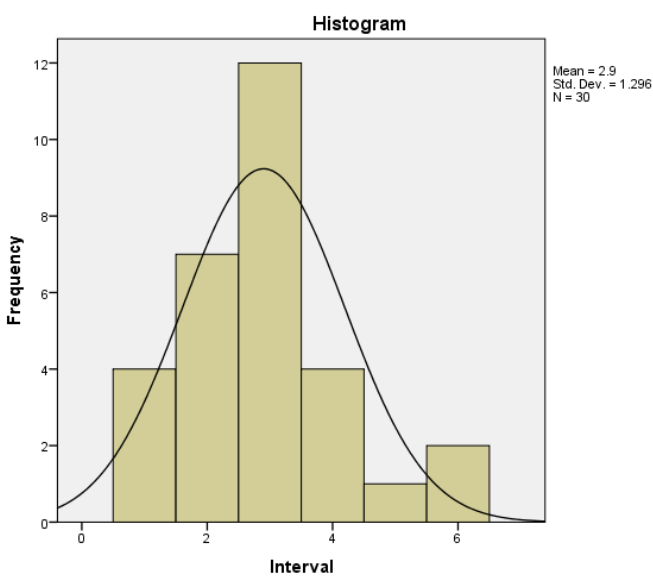

Gambar 3. Histogram Data Sub

Variabel Dukungan Terhadap Guru

dalam Implementasi Kurikulum Muatan Lokal

\section{Pembahasan}

Penelitian ini pada dasarnya bertujuan untuk mengetahui menganalisis seberapa besar pengaruh faktor-faktor determinan dalam implementasi kurikulum muatan lokal.

Tiga faktor determinan yang menjadi perhatian penelitian yaitu persepsi guru terhadap implementasi kurikulum muatan lokal $\left(\mathrm{X}_{1}\right)$, pelaksanaan pembelajaran yang dilakukan oleh guru $\left(\mathrm{X}_{2}\right)$, dan dukungan terhadap guru dalam implementasi kurikulum muatan lokal $\left(\mathrm{X}_{3}\right)$. Pembahasan hasil penelitian diuraikan sebagai berikut:

\section{Persepsi Guru terhadap Implementasi Kurikulum Muatan Lokal (X)}

Mengacu kepada hasil penelitian, persepsi guru terhadap implementasi kurikulum muatan lokal $\left(\mathrm{X}_{1}\right)$ sudah baik. Hal ini terlihat dari perbandingan skor yang diperoleh dari responden dengan skor teoritisnya. Secara teoritis, skor terendah sub variabel persepsi guru terhadap implementasi kurikulum muatan lokal $\left(\mathrm{X}_{1}\right)$ adalah 12 dan tertinggi adalah 60 . Dengan membagi ke dalam 5 rentang skala, diperoleh rentang dan kategori teoritis seperti pada Tabel 6.

\begin{tabular}{cl}
\multicolumn{2}{c}{ Tabel 6. Rentang dan Kategori Teoritis } \\
\hline Rentang Nilai & \multicolumn{1}{c}{ Kategori } \\
\hline \hline $50-60$ & Sangat Baik \\
$39-49$ & Baik \\
$28-38$ & Cukup Baik \\
$17-27$ & Kurang Baik \\
$6-16$ & Tidak Baik \\
\hline
\end{tabular}

Skor penelitian terendah untuk sub variabel persepsi guru terhadap implementasi kurikulum muatan lokal $\left(\mathrm{X}_{1}\right)$ adalah 39 dan skor tertinggi 59. Merujuk pada Tabel 6, maka 15 responden $(50 \%)$ berada pada kategori sangat baik, dan sisanya sebanyak 15 responden (50\%) berada pada kategori baik. Data tersebut menunjukkan bahwa persepsi guru terhadap implementasi kurikulum muatan lokal $\left(\mathrm{X}_{1}\right)$ sudah baik. Jika dilihat ketiga ukuran pemusatan data hasil penelitian, ketiganya berada pada kategori baik. Diketahui bahwa skor rata-rata sub variabel persepsi guru terhadap implementasi kurikulum muatan lokal $\left(\mathrm{X}_{1}\right)$ adalah 49 , skor mediannya 49,50, dan skor modusnya 47. Dapat disimpulkan bahwa persepsi guru terhadap implementasi kurikulum muatan lokal $\left(\mathrm{X}_{1}\right)$ tergolong baik.

\section{Pelaksanaan Pembelajaran Muatan Lokal yang Dilakukan oleh Guru ( $\left.\mathbf{X}_{2}\right)$}

Mengacu kepada hasil penelitian, pelaksanaan pembelajaran yang dilakukan oleh guru $\left(\mathrm{X}_{2}\right)$ sudah baik. Hal ini terlihat dari perbandingan skor yang diperoleh dari responden dengan skor teoritisnya. Secara teoritis, skor terendah sub variabel pelaksanaan pembelajaran yang dilakukan oleh guru $\left(\mathrm{X}_{2}\right)$ adalah 62 dan tertinggi adalah 310. Dengan membagi ke dalam 5 rentang skala, diperoleh rentang dan kategori teoritis seperti pada Tabel 7. 
Tabel 7. Rentang dan Kategori Teoritis

\begin{tabular}{|c|c|}
\hline Rentang Nilai & Kategori \\
\hline $260-310$ & Sangat Baik \\
\hline $209-259$ & Baik \\
\hline $158-208$ & Cukup Baik \\
\hline $107-157$ & Kurang Baik \\
\hline 56-106 & Tidak Baik \\
\hline
\end{tabular}

Skor penelitian terendah untuk sub variabel pelaksanaan pembelajaran yang dilakukan oleh guru $\left(\mathrm{X}_{2}\right)$ adalah 214 dan skor tertinggi 291. Merujuk pada Tabel 7, maka 6 responden $(20 \%)$ berada pada kategori sangat baik, dan sisanya sebanyak 24 responden (80\%) berada pada kategori baik. Data tersebut menunjukkan bahwa sub variabel pelaksanaan pembelajaran yang dilakukan oleh guru $\left(\mathrm{X}_{2}\right)$ sudah baik. Jika dilihat ketiga ukuran pemusatan data hasil penelitian, ketiganya berada pada kategori baik. Diketahui bahwa skor rata-rata sub variabel pelaksanaan pembelajaran yang dilakukan oleh guru $\left(\mathrm{X}_{2}\right)$ adalah 248,67 , skor mediannya 247,50, dan skor modusnya 247. Dapat disimpulkan bahwa sub variabel pelaksanaan pembelajaran yang dilakukan oleh guru $\left(\mathrm{X}_{2}\right)$ tergolong baik.

\section{Dukungan Terhadap Guru dalam Implementasi Kurikulum Muatan Lokal (X)}

Mengacu kepada hasil penelitian, dukungan terhadap guru dalam implementasi kurikulum muatan lokal $\left(\mathrm{X}_{3}\right)$ sudah baik. Hal ini terlihat dari perbandingan skor yang diperoleh dari responden dengan skor teoritisnya. Secara teoritis, skor terendah sub variabel dukungan terhadap guru dalam implementasi kurikulum muatan lokal $\left(\mathrm{X}_{3}\right)$ adalah 54 dan tertinggi adalah 270. Dengan membagi ke dalam 5 rentang skala, diperoleh rentang dan kategori teoritis seperti pada Tabel 8.

Tabel 8. Rentang dan Kategori Teoritis

\begin{tabular}{cl}
\hline Rentang Nilai & \multicolumn{1}{c}{ Kategori } \\
\hline \hline $227-270$ & Sangat Baik \\
$183-226$ & Baik \\
$139-182$ & Cukup Baik \\
$95-138$ & Kurang Baik \\
$51-94$ & Tidak Baik \\
\hline
\end{tabular}

Skor penelitian terendah untuk sub variabel dukungan terhadap guru dalam implementasi kurikulum muatan lokal $\left(\mathrm{X}_{3}\right)$ adalah 183 dan skor tertinggi 265. Merujuk pada Tabel 8, maka 5 responden (17\%) berada pada kategori sangat baik, dan sisanya sebanyak 25 responden (83\%) berada pada kategori baik. Data tersebut menunjukkan bahwa sub variabel dukungan terhadap guru dalam implementasi kurikulum muatan lokal $\left(X_{3}\right)$ sudah baik. Jika dilihat ketiga ukuran pemusatan data hasil penelitian, ketiganya berada pada kategori baik. Diketahui bahwa skor rata-rata sub variabel dukungan terhadap guru dalam implementasi kurikulum muatan lokal $\left(\mathrm{X}_{3}\right)$ adalah 215,23 , skor mediannya 217, dan skor modusnya 183. Dapat disimpulkan bahwa sub variabel dukungan terhadap guru dalam implementasi kurikulum muatan lokal $\left(\mathrm{X}_{3}\right)$ tergolong baik.

\section{Uji Komparatif Faktor-Faktor Determinan yang Mempengaruhi Implementasi Kurikulum Muatan Lokal Antara Sekolah Negeri dan Swasta}

Dalam penelitian ini penulis membedakan data hasil penelitian menjadi 2 kriteria berdasarkan data sampel guru yang mengajar di sekolah berstatus negeri dan swasta. Penulis juga menyusun hipotesis penelitian sebagai berikut.

$\mathrm{H}_{0}$ : Tidak terdapat perbedaan persepsi guru terhadap implementasi kurikulum muatan lokal $\left(\mathrm{X}_{1}\right)$, pelaksanaan pembelajaran yang dilakukan oleh guru $\left(\mathrm{X}_{2}\right)$, dan dukungan terhadap guru dalam implementasi kurikulum muatan lokal $\left(\mathrm{X}_{3}\right)$ antara guru yang mengajar di sekolah berstatus negeri dan swasta.

$\mathrm{H}_{\mathrm{a}}$ : Terdapat perbedaan persepsi guru terhadap implementasi kurikulum muatan lokal $\left(\mathrm{X}_{1}\right)$, pelaksanaan pembelajaran yang dilakukan oleh guru $\left(\mathrm{X}_{2}\right)$, dan dukungan terhadap guru dalam implementasi kurikulum muatan lokal $\left(\mathrm{X}_{3}\right)$ antara guru yang mengajar di sekolah berstatus negeri dan swasta.

Berdasarkan perhitungan IndependentSamples T Test menggunakan aplikasi SPSS Statistics Version 20, diperolah nilai Sig.(2- 
tailed) untuk sub variabel persepsi guru terhadap implementasi kurikulum muatan lokal $\left(\mathrm{X}_{1}\right)$ sebesar 0,274 . Untuk sub variabel pelaksanaan pembelajaran yang dilakukan oleh guru $\left(\mathrm{X}_{2}\right)$ diperolah nilai Sig.(2-tailed) sebesar 0,352 , sedangkan untuk sub variabel dukungan terhadap guru dalam implementasi kurikulum muatan lokal $\left(\mathrm{X}_{3}\right)$ diperolah nilai Sig.(2-tailed) sebesar 0,091. Selanjutnya hasil perhitungan dibandingkan dengan kriteria signifikansi pengujian sebesar 0,05 untuk menarik kesimpulan dengan mengacu pada ketentuan berikut.

$\mathrm{H}_{0}$ diterima jika $\mathrm{P}_{\text {value }}>0,05$

$\mathrm{H}_{0}$ ditolak jika $\mathrm{P}_{\text {value }}<0,05$

Lebih jelas hasil perhitungan dapat dilihat pada Tabel 9 berikut.

Tabel 9. Hasil Uji Komparatif Nilai RataRata

\begin{tabular}{ccc}
\hline $\begin{array}{c}\text { Sub } \\
\text { Variabel }\end{array}$ & Probabilitas & Signifikansi \\
\hline $\mathrm{X}_{1}$ & 0,274 & 0,05 \\
$\mathrm{X}_{2}$ & 0,352 & 0,05 \\
$\mathrm{X}_{3}$ & 0,091 & 0,05 \\
\hline
\end{tabular}

Dengan membandingkan hasil perhitungan dan signifikansi pada Tabel 9, maka diambil keputusan bahwa $\mathrm{H}_{0}$ diterima karena $\mathrm{P}_{\text {value }}>0,05$, artinya bahwa tidak terdapat perbedaan persepsi guru terhadap implementasi kurikulum muatan lokal $\left(\mathrm{X}_{1}\right)$, pelaksanaan pembelajaran yang dilakukan oleh guru $\left(\mathrm{X}_{2}\right)$, dan dukungan terhadap guru dalam implementasi kurikulum muatan lokal $\left(\mathrm{X}_{3}\right)$ antara guru yang mengajar di sekolah berstatus negeri dan swasta.

\section{PENUTUP}

Berdasarkan hasil dan pembahasan pada bagian sebelumnya, penulis dapat mengambil kesimpulan bahwa masingmasing sub variabel dari faktor-faktor determinan yang mempengaruhi implementasi kurikulum muatan lokal mulai dari persepsi guru terhadap implementasi kurikulum muatan lokal $\left(\mathrm{X}_{1}\right)$, pelaksanaan pembelajaran yang dilakukan oleh guru $\left(\mathrm{X}_{2}\right)$, dan dukungan terhadap guru dalam implementasi kurikulum muatan lokal $\left(\mathrm{X}_{3}\right)$ termasuk dalam kategori baik dan sangat baik. Tidak ada perbedaan persepsi guru terhadap implementasi kurikulum muatan lokal $\left(\mathrm{X}_{1}\right)$, pelaksanaan pembelajaran yang dilakukan oleh guru $\left(\mathrm{X}_{2}\right)$, dan dukungan terhadap guru dalam implementasi kurikulum muatan lokal $\left(X_{3}\right)$ antara guru yang mengajar di satuan pendidikan berstatus negeri dan juga swasta.

Rekomendasi yang dapat penulis berikan berdasarkan temuan hasil penelitian antara lain: Persepsi guru terhadap pembelajaran sebaiknya ditingkatkan, terutama keyakinan dalam diri guru untuk melandasi pelaksanaan pembelajaran yang terstruktur agar berdampak positif bagi siswa. Dukungan stakeholder terhadap guru dalam pembe-lajaran muatan lokal perlu dijamin keberadaannya agar guru dapat melaksanakan tugasnya dengan optimal. Bagi peneliti lanjutan, penelitian sejenis dapat dikembangkan dengan menyesuai-kan ranah kajian, sampel, dan wilayah penelitian.

\section{UCAPAN TERIMA KASIH}

Penulis menyampaikan rasa hormat dan terima kasih atas bimbingan dan arahan Dr. Laksmi Dewi, M.Pd. selama penyelesaian tulisan ini. Penulis juga mengucapkan terima kasih kepada Bapak/Ibu Guru yang telah berkenan membantu dan berpartisipasi menjadi responden dalam penelitian ini.

\section{DAFTAR PUSTAKA}

Ali, M. (2014). Memahami riset perilaku dan sosial. Jakarta: PT. Bumi Aksara.

Arifin, Z. (2014). Konsep dan model pengembangan kurikulum, Cetakan Keempat. Bandung: PT. Remaja Rosdakarya.

Arikunto, S. (2006). Prosedur penelitian, suatu pendekatan praktik. Jakarta: PT. Rineka Cipta.

Badan Pengembangan dan Pembinaan Bahasa. (2017). Badan bahasa gelar festival dan seminar nasional bahasa ibu 2017. Diakses dari: http://badanbahasa.kemdikbud.go.id/ lamanbahasa/node/2259 
Barton, G. M., Garvis, S., \& Ryan, M. E. (2014). Curriculum to the classroom: investigating the spatial practices of curriculum implementation in Queensland schools and its implications for teacher education. Australian Journal of Teacher Education, 39 (3), hlm. 166-177.

Budiwiyanto, A.

(2016). Pendokumentasian bahasa dalam upaya revitalisasi bahasa daerah yang terancam punah di Indonesia. Diakses dari: http://badanbahasa.kemdikbud.go.id/ lamanbahasa/artikel/1823/pendokum entasian-bahasa-dalam-upayarevitalisasi-bahasa-daerah-yangterancam-punah-di-i

Hamalik, O. (2009). Dasar-dasar pengembangan kurikulum. Bandung: PT. Remaja Rosdakarya.

Heriyanto, R. (2017, 20 Maret). Keberadaan bahasa Sunda semakin terancam punah. [Online]. Diakses dari: http://www.pikiranrakyat.com/hidup-

gaya/2017/03/20/keberadaan-bahasasunda-semakin-terancam-punah396798

Howley, A., dkk. (2011). Place-based education at island community school. The Journal of Environmental Education, 42(4), hlm. 216-236. DOI:

10.1080/00958964.2011.556682

Hussain, Z., Adeeb, A., \& Aslam, H. D. (2011). Curriculum implementation and feedback mechanism at secondary school level in Punjab Pakistan. International Journal of Learning \& Development, 1 (2), hlm. 92-98. DOI:10.5296/ijld.v1i2.6645

Komunitas Sekolah Riset Small Intense Class (SIC), Forum Komunikasi Mahasiswa Sekolah Pascasarjana, UPI. (2014). Ekspedisi kurikulum 2013. Bandung: CV. Alfabeta.

Lestari, S. (2012). Pengelolaan kurikulum muatan lokal (KML) bahasa Inggris SD Negeri se-kecamatan Gondokusuman Yogyakarta. Jurnal
Penelitian Ilmu Pendidikan, 5 (2), hlm. 66-73.

LIPI. (2015, 10 Desember). Bahasa daerah tergerus zaman.Diakses dari: http://lipi.go.id/berita/single/BahasaDaerah-Tergerus-Zaman/10436

Mansur, N. (2012). Urgensi kurikulum muatan lokal dalam pendidikan. Jurnal Ilmiah Didaktika, 13 (1), hlm. 68-79.

Miller, J. P. \& Seller, W. (1985). Curriculum perspectives and practices. New York \& London: Longman.

Muhyidin, A. (2009). Pemertahanan nilainilai budaya lokal dalam pembelajaran sastra di sekolah. Diakses dari: http://badanbahasa.kemdikbud.go.id/ lamanbahasa/node/306

Mulyasa, E. (2010). Kurikulum tingkat satuan penddikan, suatu panduan praktis. Bandung: PT. Remaja Rosdakarya.

Mulyasa, E. (2016). Guru dalam implementasi kurikulum 2013. Bandung: PT. Remaja Rosdakarya.

Musfah, J. (2015). Peningkatan kompetensi guru: melalui pelatihan dan sumber belajar teori dan praktek. Jakarta: Prenadamedia Group.

Natadipura, Y. (2015, 25 Juni). Bahasa sunda tergerus penutur.Diakses dari: https://www.kompasiana.com/yan_6 7/bahasa-sunda-tergeruspenutur_550ae58ca33311921c2e3b2 2

Ornstein, A. C. \& Hunkins, F. P. (2017). Curriculum: foundations, principles and issues, 7th Edition. New Jersey: Pearson Education, Inc.

Peraturan Gubernur Jawa Barat 2013 No. 69, Pembelajaran Muatan Lokal Bahasa dan Sastra Daerah pada Jenjang Pendidikan Dasar dan Menengah.

Peraturan Menteri Pendidikan dan Kebudayaan 2007 No. 16, Standar Kualifikasi Akademik dan Kompetensi Guru. 
Peraturan Menteri Pendidikan dan Kebudayaan 2014 No. 79, Muatan Lokal Kurikulum 2013.

Pikiran Rakyat. (2010, 20 Februari). Bahasa sunda terancam punah. Diakses dari: http://www.pikiranrakyat.com/bandungraya/2010/02/20/107687/bahasasunda-terancam-punah

Pusat Data dan Statistik Pendidikan dan Kebudayaan. (2016). Statistik kebudayaan 2016. Jakarta: Sekretariat Jenderal, Kementerian Pendidikan dan Kebudayaan.

Rep-Humas Setda Jabar. (2016, 1 Desember). Buka kongres basa sunda $X$, Aher: bahasa adalah tanda. Diakses dari: http://www.jabarprov.go.id/index.ph p/news/20241/2016/12/01/Buka-

Kongres-Basa-Sunda-X-AherBahasa-Adalah-Tanda

Ririmasse, M. (2014). Pengetahuan arkeologi sebagai muatan lokal: penerapannya di Maluku. Kapata Arkeologi, 10 (1), hlm. 13-22.

Rusman. (2012). Manajemen kurikulum. Jakarta: Rajagrafindo Persada.

Sobarna, C. (2007). Bahasa sunda sudah di ambang pintu kematiankah? Makara, Sosial Humaniora, 11 (1), hlm. 1317. [Online]. Diakses dari: https://media.neliti.com/media/public ations/4345-ID-bahasa-sunda-sudahdi-ambang-pintu-kematiankah.pdf

Sobel, D. (2004). Place-based education: connecting classrooms and communities. Massachusetts: The Orion Society.

Sukmadinata, N. S. (2016). Pengembangan kurikulum: teori dan praktek. Bandung: Remaja Rosdakarya.

Sumardjo, J. (2011). Sunda, pola rasionalitas budaya. Bandung: Kelir.

Suyanto, B. (2015). Implementasi kebijakan pembinaan bahasa daerah di kabupaten Jember, Situbondo dan Banyuwangi. Semiotika, 18(1), hlm. 14-28.

Suyatno, S. (2011). Revitalisasi kearifan lokal sebagai identitas bangsa di tengah perubahan nilai sosiokultural. Metasastra, 4 (1), hlm. 82-89. [Online]. Diakses dari: file:///D:/downloaded\%20files/156338-1-SM\%20(1).pdf

Suyitno, Al. (1999). Implementasi kurikulum muatan lokal di sekolah. Cakrawala Pendidikan, 18 (4), hlm. 174-180.

Tondo, F. H. (2009). Kepunahan bahasabahasa daerah: faktor penyebab dan implikasi etnolinguistis. Jurnal Masyarakat \& Budaya, 11 (2), hlm. 277-296.

Wahyudin, D. (2014). Manajemen kurikulum. Bandung: Remaja Rosdakarya.

Yati, D. (2015). Menyelamatkan bahasa daerah melalui pembelajaran bahasa yang komunikatif. Prosiding Seminar Nasional Bulan Bahasa (hlm. 157170), Universitas Bengkulu, Indonesia. 